\title{
Vitamin D receptor and calcium-sensing receptor polymorphisms and colorectal cancer survival in the Newfoundland population
}

Yun Zhu ${ }^{1,2}$, Peizhong Peter Wang ${ }^{* 1,2}$, Guangju Zhai ${ }^{3,4}$, Bharati Bapat ${ }^{5}$, Sevtap Savas ${ }^{3,6}$, Jennifer R Woodrow ${ }^{1}$, Ishor Sharma ${ }^{1}$, Yuming $\mathrm{Li}^{7}$, Xin Zhou ${ }^{7}$, Ning Yang ${ }^{7}$, Peter T Campbell ${ }^{8}$, Elizabeth Dicks ${ }^{9}$, Patrick S Parfrey ${ }^{9}$ and John R Mclaughlin ${ }^{10}$

${ }^{1}$ Division of Community Health and Humanities, Faculty of Medicine, Memorial University of Newfoundland, St John's, NL A1B 3V6, Canada; ${ }^{2}$ School of Public Health, Tianjin Medical University, Tianjin, 300070, China; ${ }^{3}$ Discipline of Genetics, Faculty of Medicine, Memorial University of Newfoundland, St John's, NL A1B 3V6, Canada; ${ }^{4}$ Menzies Research Institute, University of Tasmania, Hobart, TAS 7000, Australia; ${ }^{5}$ Department of Laboratory Medicine and Pathobiology, Department of Surgery, University of Toronto, Toronto, ON M5T 3L9, Canada; ${ }^{6}$ Discipline of Oncology, Faculty of Medicine, Memorial University of Newfoundland, St John's, NL A1B 3V6, Canada; 'Tianjin Key Laboratory of Cardiovascular Remodeling and Target Organ Injury, Pingjin Hospital Heart Center, Logistics University of Chinese People's Armed Police Force, Tianjin, 300309, China; ${ }^{8}$ Epidemiology Research Program, American Cancer Society, Atlanta, GA 30303; ${ }^{9}$ Clinical Epidemiology Unit, Faculty of Medicine, Memorial University of Newfoundland, St John's, NL A1B 3V6, Canada and ${ }^{10}$ Division of Epidemiology, Public Health Ontario, Toronto, ON M5G 1V2, Canada

Background: Increased serum levels of vitamin $D$ and calcium have been associated with lower risks of colorectal cancer (CRC) incidence and mortality. These inverse associations may be mediated by the vitamin D receptor (VDR) and the calcium-sensing receptor (CASR). We investigated genetic variants in VDR and CASR for their relevance to CRC prognosis.

Methods: A population-based cohort of 531 CRC patients diagnosed from 1999 to 2003 in Newfoundland and Labrador, Canada, was followed for mortality and cancer recurrence until April 2010. Germline DNA samples were genotyped with the Illumina OmniQuad 1 Million chip. Multivariate Cox models assessed 41 tag single-nucleotide polymorphisms and relative haplotypes on VDR and CASR in relation to all-cause mortality (overall survival, OS) and disease-free survival (DFS).

Results: Gene-level associations were observed between VDR and the DFS of rectal cancer patients $(P=0.037)$ as well as between CASR and the OS of colon cancer patients $(P=0.014)$. Haplotype analysis within linkage blocks of CASR revealed the G-G-G-G-GA-C haplotype (rs10222633-rs10934578-rs3804592-rs17250717-A986S-R990G-rs1802757) to be associated with a decreased OS of colon cancer ( $\mathrm{HR}, 3.15 ; 95 \% \mathrm{Cl}, 1.66-5.96)$. Potential interactions were seen among prediagnostic dietary calcium intake with the CASR R990G ( $\left.P_{\text {int }}=0.040\right)$ and the CASR G-T-G-G-G-G-C haplotype for rs10222633-rs10934578-rs3804592-rs17250717-A986SR990G-rs1802757 ( $P_{\text {int }}=0.017$ ), with decreased OS time associated with these variants limited to patients consuming dietary calcium below the median, although the stratified results were not statistically significant after correction for multiple testing.

Conclusions: Polymorphic variations in VDR and CASR may be associated with survival after a diagnosis of CRC.

${ }^{*}$ Correspondence: Professor PP Wang; E-mail: pwang@mun.ca

Received 12 May 2017; revised 20 June 2017; accepted 3 July 2017; published online 1 August 2017

(C) 2017 Cancer Research UK. All rights reserved 0007-0920/17 
Evidence from both epidemiological (Giovannucci et al, 2006; Otani et al, 2007) and experimental studies (Harris and Go, 2004; Leyssens et al, 2013) support a reduced risk of colorectal cancer (CRC) by higher intake or blood levels of vitamin D. Vitamin D mediates its action through binding to the vitamin $\mathrm{D}$ receptor (VDR), a member of the nuclear receptor superfamily that is expressed in various cell types, including colorectal epithelial cells. This binding enables the transactivation of target genes that promote cellular differentiation (Palmer et al, 2001), induce apoptosis (Donohue and Demay, 2002), and inhibit angiogenesis and proliferation (Kallay et al, 2001). Thus, VDR has been implicated in colorectal carcinogenesis. Another gene that influences vitamin D metabolism is the calcium-sensing receptor (CASR), which is essential for calcium homeostasis and cellular growth kinetics (Chattopadhyay et al, 2000; Jenab et al, 2009). In the CASR promoter region, vitamin $\mathrm{D}$ response elements have been discovered, providing evidence at the molecular level for a potential interaction between vitamin D and calcium in CRC (Canaff and Hendy, 2002; Dong et al, 2008). Recent studies have also demonstrated a critical role of CASR as a tumour suppressor in the large intestine (Aggarwal et al, 2015). Expression of this receptor has been shown to be reduced in colon cancer cells as compared to normal colonic epithelial cells (Sheinin et al, 2000).

Current molecular studies have identified numerous singlenucleotide polymorphisms (SNPs) in the human VDR and CASR genes, but only a handful that are considered potentially functional have been examined in relation to CRC risk, including FokI (rs10735810) (Jenab et al, 2009; Sarkissyan et al, 2014), BsmI (rs1544410) (Jenab et al, 2009; Bai et al, 2012), ApaI (rs7975232) (Laczmanska et al, 2014; Sarkissyan et al, 2014), and TaqI (rs731236) (Laczmanska et al, 2014) in VDR, and A986S (rs1801725) (Dong et al, 2008; Mahmoudi et al, 2014) and R990G (rs1042636) (Dong et al, 2008) in CASR. Several studies have linked one or more of these variants to CRC and, particularly, the VDR BsmI bb (GG) (Jenab et al, 2009; Bai et al, 2012) and CASR A986S (TT) genotypes (Bacsi et al, 2008) were related to an increased risk of CRC. However, very few relevant studies on CRC survival have been published and none of these were from the Canadian population (Bacsi et al, 2008; Hubner et al, 2008; Egan et al, 2010; Fedirko et al, 2012; Perna et al, 2013). Limited evidence shows no association of polymorphisms in VDR and CASR with survival after CRC diagnosis, but can be criticised for limited power or incomplete coverage of the variation within the gene (Bacsi et al, 2008; Fedirko et al, 2012). In addition, little is known regarding how pre- or postdiagnostic dietary factors could interact with $V D R$ and CASR genotypes to influence CRC prognosis (Fedirko et al, 2012). This is important especially because longterm eating habits prior to diagnosis may affect postdiagnostic diet, and because cancer patients may have a strong desire to make positive changes, and may benefit from recommendations on a healthy diet and supplement use as a complement to their therapy (Patterson et al, 2003; Fedirko et al, 2012).

Therefore, in this analysis, we examined the hypothesis that genetic variations in VDR or CASR influence survival among CRC patients with possible effect modification by prediagnostic dietary vitamin $\mathrm{D}$ and calcium intakes within the context of a populationbased cohort study in Newfoundland.

\section{MATERIALS AND METHODS}

Study population. The study was performed as part of the Newfoundland Familial Colorectal Cancer Study (NFCCS) effort to investigate environmental and genetic influences on CRC risk and survival outcome. The detailed rationale and methodology of the NFCCS has been described elsewhere (Green et al, 2007; Woods et al, 2010; Zhu et al, 2014). Briefly, histologically confirmed cases of CRC diagnosed under age 75 between 1997 and 2003 were recruited in the province of Newfoundland \& Labrador. The 531 patients (201 women and 330 men) included in the current study represented a subset of patients enrolled in the NFCCS $(n=737)$ who had both the disease-outcome data and a germline DNA sample available. Informed consent was obtained for all participants, and the study was carried out with the approval by the Health Research Ethics Authority of Memorial University of Newfoundland in accordance with the tenets of the declaration of Helsinki.

Diet assessment and baseline information collection. Detailed information about demographics, race and ethnicity, individual behaviors, medical history, detailed cancer family history, bowel screening history, and use of alcohol and tobacco was gathered via self-administered Family History Questionnaires (FHQ) and Personal History Questionnaires (PHQ). Participants also completed a 169-item Food Frequency Questionnaire (FFQ) at the time of recruitment that addressed their dietary intake in the one year prior to their diagnosis. The FFQ was self-administered and semiquantitative that had previously been validated in the Newfoundland population (Liu et al, 2013). The nutrient intakes from diet were calculated by multiplying the frequency of consumption of each food item by the nutrient content per average unit (Sun et al, 2011).

Study outcomes. Study participants were followed for recurrence and mortality from the date of cancer diagnosis until April 2010, with a combination of active follow-up (periodic follow-up questionnaires, for example, FHQ) and record linkage to death certificates, pathology reports, autopsy records, physicians' notes, and surgical reports. The additional data were obtained from the Dr H. Bliss Murphy Cancer Care Foundation. The main outcomes used for this study were overall survival (OS) and disease-free survival (DFS). The end-point event for the OS analysis was death from all-causes and for the DFS analysis was death from any cause, CRC recurrence, or metastasis, whichever came first.

Genotyping and SNP selection. Genotyping of peripheral blood DNA samples was performed using the Illumina Human OmniQuad Bead chip that contains about 1.1 million SNPs at Centrillion Biosciences (USA). For quality control purposes, genomic DNA from 200 duplicate samples were sent to the Laboratory of $\mathrm{Dr}$ Stephen Gruber (Director, USC Norris Comprehensive Cancer Center, Los Angeles) for genotyping using the Affymetrix Axiom myDesign GW Array Plate, which contains 1.3 million probes. SNPs with genotype concordance $<97 \%$ between the two platforms were dropped from all analyses.

We used an aggressive tagging approach to limit the number of SNPs examined to the most relevant. Tagging SNPs capturing most of the common variation in the candidate gene regions were identified using Plink v1.07 based on the following criteria: the minor allele frequency of the $\mathrm{SNP} \geqslant 5 \%$; pairwise $r^{2}>0.9$; and at least 50 base pairs from any adjacent SNPs (de Bakker et al, 2005). The regions analysed included about $103 \mathrm{~kb}$ of the CASR gene and $65 \mathrm{~kb}$ of the VDR gene. This process identified 24 SNPs for $V D R$ and 14 SNPs for CASR. Additionally, a priori, we also selected 4 high interest SNPs reported in previous CRC studies, including VDR BsmI, CASR R990G, CASR rs1802757, and CASR A986S. For all genotypes, the call frequency was $>99.5 \%$ except for one SNP (VDR rs2238135, 99.2\%). The distribution of the genotypes of all SNPs examined in this study fitted Hardy-Weinberg proportions, with the exception of $V D R \operatorname{rs} 3847987(P<0.001)$, which was excluded from analysis.

Our protocol for MSI testing and mutation detection on BRAF V600E in tumour DNA has been described elsewhere (Woods et al, 2010). MSI status was determined using 5 to 10 microsatellite 
markers. Mutant alleles in the BRAF gene were detected using the allele-specific polymerase chain reaction (AS-PCR) technique (Woods et al, 2010).

Statistical analysis. The log-rank test compared the survival distributions across groups of baseline factors. We utilised a principal component (PC) analysis that accounts for linkage disequilibrium (LD) between multiple SNPs to test for an overall association of a gene with survival of CRC patients (Gauderman et al, 2007). Briefly, this approach computed uncorrelated linear combinations of the original SNPs, grouped as PCs, that explain the greatest amount of variance across the gene. Then, PCs that cumulatively explain at least $80 \%$ of the variance were retained and included in a Cox proportional hazards regression analysis with CRC survival as the outcome. Using a likelihood ratio test, we calculated a $P$-value for the global gene-outcome association by comparing models with and without selected PCs with the number of degrees of freedom equal to the number of PCs. Overall survival and DFS were the main outcomes, each stratified by anatomical site (colon and rectum).

The data were further explored using a single-SNP analysis, followed by the haplotype analysis. For every individual SNP, the associations with overall and DFS in CRC patients were estimated by hazard ratios (HRs) and 95\% confidence intervals (CIs), while assuming an additive model by Cox regression analysis, adjusted for sex, race, age at diagnosis, disease stage at diagnosis, reported screening procedure, marital status, MSI status, and BRAF mutation status when applicable. These covariates were retained in the final model because they either entered the model at $P<0.1$ or altered the parameter estimates by $>10 \%$. The proportional hazards assumption was verified by testing the statistical significance of time-by-covariate interactions for each covariate in the Cox model. To control type I error inflation, $P$-values were then adjusted for multiple comparisons using the approach specifically created for correlated tests due to LD by Conneely and Boehnke, 2007. For the haplotype analyses, LD plots were generated using the Haploview version 4.2 to evaluate haplotype block structure based on the criteria of Gabriel et al, 2002. Haplotype frequencies were estimated using the expectation maximisation algorithm accounting for ambiguous linkage phase, and the association between individual haplotype and CRC survival was assessed by modelling all haplotypes simultaneously with the most frequent haplotype as the reference. Bonferroni correction for multiple testing was performed for thirty-six haplotypes yielding an adjusted $P$-value of 0.0014 . A global $P$ value for each haplotype block was obtained with a Wald test. Haplotype analyses were performed using SimHap GUI version 1.0.2 (Carter et al, 2008). Gene-environment $(\mathrm{G} \times \mathrm{E})$ interactions were tested through stratified analysis and verified with the Wald method by introducing a multiplicative interaction term into the model and assessing its significance. The $\mathrm{G} \times \mathrm{E}$ analyses, a priori, were not adjusted for multiple comparisons. All tests were twosided. Other data management and analyses were performed with SAS software version 9.4 (SAS Institute, Cary, NC, USA).

\section{RESULTS}

Patient characteristics and clinical predictors. The study sample consisted of 330 men and 201 women (Table 1). The mean age of the study population was $60.7 \pm 9.2 \mathrm{yrs}$, with $96.9 \%$ of the participants being white, $11.5 \%$ reporting a bowel screening history, and $66.0 \%$ having had tumours at the colon subsite. Information on MSI status was available for a total of 503 patients, with $11.5 \%$ classified as MSI-H and $88.5 \%$ as MSS/MSI-L. Salient characteristics were largely comparable between the NFCCS patients included and those excluded from the current study due to lack of genotype/disease-outcome data. At the end of our study (median follow-up time, 6.4 years), 183 (34.5\%) of the 531 patients had died. In the univariate analysis, male gender, other ethnicity, advanced stage at diagnosis (III/IV), chemoradiotherapy, and MSS/ MSI-L tumours were significantly associated with reduced OS time, whereas bowel screening procedure, tumour location, and $B R A F$ mutation status were not associated with OS among the 531 CRC patients included in this study.

Association of $V D R$ and CASR with survival of CRC patients. $\mathrm{PC}$ analysis was conducted to assess whether there was an overall gene-level association between $V D R$ or CASR and CRC survival (Table 2). At the gene level, we observed no meaningful relationships for VDR or CASR and CRC survival. However, after stratification by colorectal subsite, the VDR gene exhibited a marginally significant association with the DFS among patients with rectal cancer (Global $P=0.037$ ), while the CASR gene was related to OS in colon cancer patients at a significance level of 0.05 (Global $P=0.014$ ).

In analyses of individual SNPs within each gene, a total of four SNPs in VDR and two SNPs in CASR were related to OS under an additive model (Supplementary Tables 1 and 2). However, multiple testing adjustment revealed one association of marginally statistical significance for VDR (BsmI polymorphism, rs1544410) and the OS of all CRC ( $\left.P_{\text {unadjusted }}=0.002, P_{\text {adjusted }}=0.058\right)$. Specifically, the $\mathrm{G}$-allele was related to worse OS as compared with the A-allele (HR per G allele, 1.15; 95\% CI, 1.17-1.94) (Figure 1). For DFS, no SNPs approached statistical significance after adjusting for multiple comparisons. Given that SNP prevalence varies across populations, analyses were repeated among those with European ancestry ('white') alone, which produced similar findings.

Haplotypes and survival of CRC patients. To evaluate potential epistatic or combined effects of SNPs, haplotype analysis was conducted to derive haplotype groups within linkage equilibrium blocks of each gene. We identified five major blocks on $V D R$ and four blocks on CASR, respectively (Supplementary Figure 1, Table 3). For the VDR gene, the haplotype A-T-G in LD block 1 (rs11574143-TaqI-BsmI), which contained the borderline significant BsmI risk $G$ allele from previous single SNP analysis, was associated with a reduced OS of rectal cancer in comparison to the most common haplotype (HR, 2.53; 95\% CI, 1.20-5.34; block global $P=0.027$ ), although this association was no longer significant when Bonferroni's correction was applied. For $C A S R$, a less frequent (4.2\%) haplotype designated as G-G-G-G-G-A-C in block 4 of CASR (rs10222633-rs10934578-rs3804592-rs17250717rs1801725-rs1042636-rs1802757) was associated with a marked increase in odds of all-cause mortality among patients with colon cancers (HR, 3.15; 95\% CI, 1.66-5.96; block global $P=0.001$ ). This association remained significant after Bonferroni correction $(P<0.0014)$. Results were similar for DFS.

Gene-diet interactions. We evaluated relationships between $V D R$ or CASR variations and OS among CRC patients after stratification by dietary vitamin $\mathrm{D}$ and calcium intakes (Supplementary Table 3 ). We saw HRs $>1$ for CASR SNP rs1042636 (R990G) (HR, 2.21; $\left.95 \% \mathrm{CI}, 1.37-3.56 ; P_{\text {int }}=0.040\right)$ and the haplotype G-T-G-G-G-GC in CASR LD block 4 (HR, 2.21; 95\% CI, 1.36-3.58; $\left.P_{\text {int }}=0.017\right)$ in the stratum with calcium intake below the median, although the associations lost significance after adjustment for multiple tests. No evidence for modification by dietary vitamin $\mathrm{D}$ intake was observed.

\section{DISCUSSION}

In this study, $V D R$ and $C A S R$ genes were associated with DFS and OS of CRC, respectively, at the gene level. Particularly, VDR BsmI 
Table 1. Demographical and clinicopathological characteristics of patients in the Newfoundland Familial Colorectal Cancer Study (NFCCS)

Subjects included in this study $(N=531) \quad$ Subjects without genotype/ disease-outcome information $(N=206$ )

\begin{tabular}{|c|c|c|c|c|c|}
\hline Characteristic & No. patients (\%) & No. deaths (\%) & $\operatorname{MST}(y)^{a}$ & $P_{\text {log-rank }}{ }^{a}$ & No. patients (\%) \\
\hline Age at diagnosis $(y)^{b}$ & $60.7 \pm 9.2$ & $61.3 \pm 9.7$ & - & - & $62.1 \pm 9.6$ \\
\hline $\begin{array}{l}\text { Sex } \\
\text { Female } \\
\text { Male }\end{array}$ & $\begin{array}{l}201(37.9) \\
330(62.1)\end{array}$ & $\begin{array}{r}56(27.9) \\
127(38.5)\end{array}$ & $\begin{array}{l}6.5 \\
6.3\end{array}$ & 0.005 & $\begin{array}{r}83(40.3) \\
123(59.7)\end{array}$ \\
\hline $\begin{array}{l}\text { Race } \\
\text { White } \\
\text { Other }\end{array}$ & $\begin{array}{c}439(96.9) \\
14(3.1)\end{array}$ & $\begin{array}{r}133(30.3) \\
8(57.1)\end{array}$ & $\begin{array}{l}6.4 \\
4.7\end{array}$ & 0.009 & $\begin{array}{c}27(93.1) \\
2(6.9)\end{array}$ \\
\hline $\begin{array}{l}\text { Reported screening procedure } \\
\text { Yes } \\
\text { No }\end{array}$ & $\begin{array}{r}52(11.5) \\
401(88.5)\end{array}$ & $\begin{array}{r}10(19.2) \\
131(32.7)\end{array}$ & $\begin{array}{l}6.6 \\
6.4\end{array}$ & 0.059 & $\begin{array}{r}7(24.1) \\
22(75.9)\end{array}$ \\
\hline $\begin{array}{l}\text { Tumour location } \\
\text { Colon } \\
\text { Rectum }\end{array}$ & $\begin{array}{l}341(66.0) \\
176(34.0)\end{array}$ & $\begin{array}{r}110(32.3) \\
65(36.9)\end{array}$ & $\begin{array}{l}6.4 \\
6.3\end{array}$ & 0.444 & $\begin{array}{r}124(72.1) \\
48(27.9)\end{array}$ \\
\hline $\begin{array}{l}\text { Stage at diagnosis } \\
\text { I/II } \\
\text { III/IV }\end{array}$ & $\begin{array}{l}302(56.9) \\
229(43.1)\end{array}$ & $\begin{array}{r}76(25.2) \\
107(46.7)\end{array}$ & $\begin{array}{l}6.6 \\
6.0\end{array}$ & $<0.001$ & $\begin{array}{r}56(27.2) \\
150(72.8)\end{array}$ \\
\hline $\begin{array}{l}\text { Surgery } \\
\text { Yes } \\
\text { No }\end{array}$ & $\begin{array}{c}516(97.2) \\
15(2.8)\end{array}$ & $\begin{array}{r}177(34.3) \\
6(40.0)\end{array}$ & $\begin{array}{l}6.4 \\
6.8\end{array}$ & 0.790 & $\begin{array}{c}204(99.0) \\
2(1.0)\end{array}$ \\
\hline $\begin{array}{l}\text { Chemoradiotherapy } \\
\text { Yes } \\
\text { No }\end{array}$ & $\begin{array}{l}106(20.5) \\
411(79.5)\end{array}$ & $\begin{array}{r}33(41.51) \\
131(31.87)\end{array}$ & $\begin{array}{l}6.0 \\
6.4\end{array}$ & 0.036 & $\begin{array}{r}33(19.2) \\
139(80.8)\end{array}$ \\
\hline $\begin{array}{l}\text { MSI status } \\
\text { MSS/MSI-L } \\
\text { MSI-H }\end{array}$ & $\begin{array}{r}445(88.5) \\
58(11.5)\end{array}$ & $\begin{array}{r}168(37.8) \\
6(10.3)\end{array}$ & $\begin{array}{l}6.3 \\
6.7\end{array}$ & $<0.001$ & $\begin{array}{c}190(92.2) \\
16(7.7)\end{array}$ \\
\hline $\begin{array}{l}\text { BRAF mutation status } \\
\text { Wild type } \\
\text { BRAF mutant } \\
\text { Dietary vitamin D intake }(\mu \mathrm{g} / \mathrm{d})^{\mathrm{b}} \\
\text { Dietary calcium intake }(\mathrm{mg} / \mathrm{d})^{\mathrm{b}}\end{array}$ & $\begin{array}{c}432(89.8) \\
49(10.2) \\
6.3 \pm 3.5 \\
965.6 \pm 460.7\end{array}$ & $\begin{array}{c}153(35.4) \\
15(30.6) \\
7.0 \pm 4.2 \\
1024.8 \pm 504.2\end{array}$ & $\begin{array}{l}6.4 \\
6.3 \\
- \\
-\end{array}$ & $\begin{array}{l}0.370 \\
- \\
-\end{array}$ & $\begin{aligned} 165 & (84.2) \\
31 & (15.8) \\
5.5 & \pm 3.0 \\
888.3 & \pm 427.8\end{aligned}$ \\
\hline
\end{tabular}

\section{Table 2. Association between VDR and CASR genes and colorectal cancer overall and disease-free survival ( $\boldsymbol{n}=531$ )}

\begin{tabular}{|c|c|c|c|c|c|c|}
\hline & \multicolumn{3}{|c|}{ Overall survival HR $(95 \% \mathrm{Cl})^{a}$} & \multicolumn{3}{|c|}{ Disease-free survival HR $(95 \% \mathrm{Cl})^{a}$} \\
\hline \multicolumn{7}{|l|}{ VDR } \\
\hline PC2 & $0.99(0.83-1.17)$ & $0.85(0.68-1.07)$ & $1.41(1.01-1.98)$ & $1.00(0.84-1.19)$ & $0.84(0.68-1.04)$ & $1.78(1.27-2.50)$ \\
\hline PC3 & $0.87(0.74-1.03)$ & $0.90(0.73-1.11)$ & $0.81(0.58-1.11)$ & $0.91(0.77-1.07)$ & $0.95(0.77-1.17)$ & $0.74(0.55-1.00)$ \\
\hline PC4 & $1.03(0.87-1.21)$ & $1.07(0.87-1.12)$ & $0.91(0.66-1.26)$ & $1.05(0.90-1.23)$ & $1.12(0.91-1.38)$ & $0.83(0.62-1.11)$ \\
\hline PC8 & $0.98(0.83-1.17)$ & $0.90(0.73-1.11)$ & $1.26(0.90-1.77)$ & $1.02(0.86-1.20)$ & $0.87(0.71-1.07)$ & $1.60(1.17-2.17)$ \\
\hline Global $P^{b}$ & 0.201 & 0.193 & 0.206 & 0.320 & 0.241 & 0.037 \\
\hline \multicolumn{7}{|l|}{ CASR } \\
\hline PC1 & $1.09(0.91-1.29)$ & $1.04(0.84-1.30)$ & $1.25(0.90-1.74)$ & $1.10(0.93-1.29)$ & $1.02(0.83-1.26)$ & $1.29(0.95-1.75)$ \\
\hline PC2 & $0.94(0.80-1.10)$ & $0.84(0.68-1.04)$ & $1.20(0.90-1.61)$ & $0.96(0.83-1.12)$ & $0.92(0.76-1.12)$ & $1.15(0.89-1.49)$ \\
\hline PC3 & $1.12(0.95-1.31)$ & $1.23(1.01-1.50)$ & $1.07(0.81-1.41)$ & $1.13(0.98-1.30)$ & $1.15(0.95-1.39)$ & $1.15(0.91-1.44)$ \\
\hline Global $P^{b}$ & 0.209 & 0.014 & 0.486 & 0.258 & 0.075 & 0.492 \\
\hline
\end{tabular}




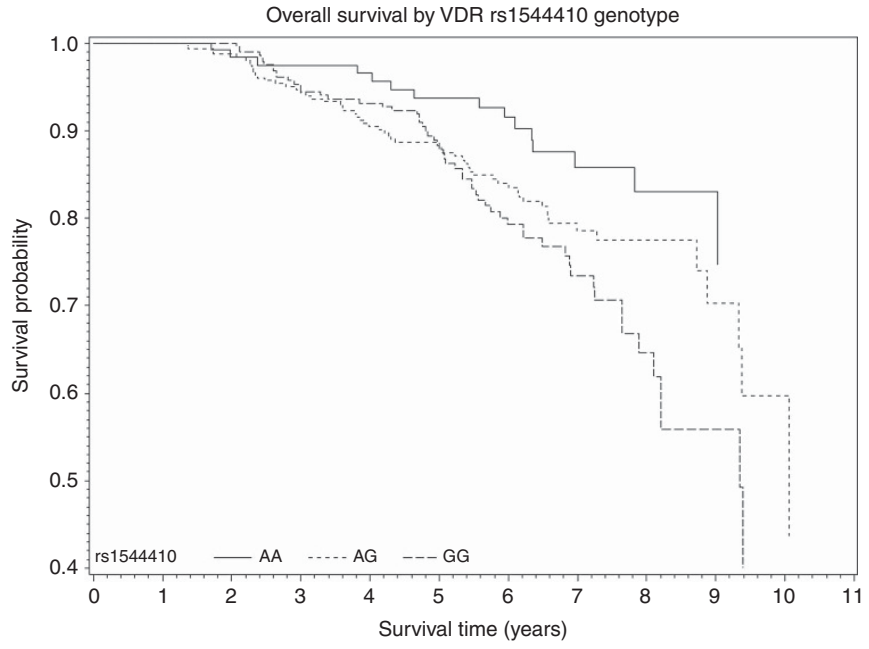

Figure 1. Overall survival curves by VDR rs1544410 genotype.

Adjusted for age at diagnosis, sex, race, stage at diagnosis, reported screening procedure, marital status, and MSI status.

polymorphism exhibited marginally significant association with the OS of CRC patients after adjustment for multiple comparisons. Haplotype analyses showed that the CASR block 4 haplotype G-GG-G-G-A-C, defined by rs10222633-rs10934578-rs3804592rs17250717-rs1801725-rs1042636-rs1802757, was associated with a reduced OS among colon cancer patients.

Experimental work indicates that vitamin D has pleiotropic biological activities with complex anticancer properties, which include inhibition of cell proliferation, invasion, induction of apoptosis, cell cycle arrest, as well as simulation of differentiation (Palmer et al, 2001). The VDR has been proposed as a potential mediator that could modulate the effects of vitamin D. For example, $V D R$ interacts with $\beta$-catenin and inhibits $\beta$-catenin signalling that is deregulated in most CRCs (Palmer et al, 2001; Egan et al, 2010). Through the nuclear VDR, $1,25(\mathrm{OH})_{2} \mathrm{D}_{3}$ induces E-cadherin, increases $\beta$-catenin nuclear export, and inhibits $\beta$-catenin gene regulatory activity to hinder proliferation and loss of differentiation in the early stage of carcinogenesis (Palmer et al, 2001). VDR is highly polymorphic with over 100 known allelic variants. Some polymorphisms may have functional importance and thus have been evaluated in previous association studies on CRC. Specifically, the FokI translational start codon polymorphism alters the $V D R$ structurally, with the F-variant $V D R$ being three amino acids shorter and functionally more effective than the protein produced from the $\mathrm{f}$ allele (Miyamoto et al, 1997; Wong et al, 2003). BsmI (intron 8), ApaI (intron 8) and TaqI (exon 9) polymorphisms have been reported to influence $V D R$ expression and thus serum levels of $1,25(\mathrm{OH})_{2} \mathrm{D}_{3}$, but they are speculated to affect $V D R$ function through linkage disequilibrium with other mutations in the $3^{\prime}$-UTR region that alter mRNA transcriptional activity and stability (Ingles et al, 1997; Kim et al, 2013). Although not a universal finding, the B allele of the VDR BsmI polymorphism has been found to be linked with a reduced risk of CRC (Jenab et al, 2009; Bai et al, 2012). Carriage of the variant FokI allele revealed either null (Peters et al, 2001; Slatter et al, 2001) or conflicting associations (Ingles et al, 2001; Wong et al, 2003; Park et al, 2006). With regard to survival after cancer diagnosis, several SNPs and haplotypes in VDR gene that are related to lower VDR function or expression (Cdx2, FokI and G-T-C for Cdx2-FokIBsmI) have been linked with poorer survival for a variety of cancers such as non-small cell lung (Zhou et al, 2006; Heist et al, 2008) and epithelial ovarian (Tamez et al, 2009) cancers. Similar to the results for CRC incidence, in our study, the variant B (A) allele of the VDR BsmI appeared to be associated with a reduction in risk of all-cause mortality among CRC patients; yet no association was detected for VDR FokI polymorphism. Few studies have been published on VDR polymorphisms and CRC survival (Hubner et al, 2008; Egan et al, 2010; Fedirko et al, 2012; Perna et al, 2013; Zgaga et al, 2014). Nevertheless, these studies did not observe any significant associations of $V D R$ variants with CRC survival. In our study, the variant B (A) allele of the VDR BsmI appeared to be associated with a reduction in risk of all-cause mortality among CRC patients; yet no association was detected for VDR FokI polymorphism. The inconsistencies in findings with previous studies may be explained by differences in population, other environmental factors (e.g., diet and lifestyle), and incomplete coverage of the gene in some studies (Hubner et al, 2008; Fedirko et al, 2012; Perna et al, 2013; Zgaga et al, 2014). While we do not presume to know how the VDR BsmI SNP influences survival for $\mathrm{CRC}$, the pathway may be involved in the biological response to treatments. As such, the BsmI polymorphism warrants further investigation in terms of its role in treatment response and patient prognosis in CRC.

Another gene analysed in the present study is the CASR. The CASR is crucial for the maintenance of extracellular calcium homeostasis by affecting parathyroid hormone secretion and calcium reabsorption (Chattopadhyay et al, 2000; Jenab et al, 2009). It may also influence vitamin D metabolism. CASR has been implicated in breast and prostate cancers (Jeong et al, 2016). Indeed, several commonly studied CASR polymorphisms, including rs1801725 (Speer et al, 2002), rs1042636 (Hibler et al, 2012), rs10934578, rs12485716, rs2270916 and rs4678174 (Dong et al, 2008), have been related to the risk of CRC in some studies, but not others (Jenab et al, 2009; Jacobs et al, 2010; Mahmoudi et al, 2014). In the work by Kim et al, 2013, these SNPs were significant only under low calcium intake. Despite the many studies investigating CASR and CRC risk, we found only two published papers (Bacsi et al, 2008; Fedirko et al, 2012) that evaluated the association of CASR and CRC survival and observed no relationship, though only one SNP (rs1801725) was included in both studies. In the current study, none of these high-interest SNPs in the literature (rs10934578, rs1801725 and rs1042636) were significantly related to CRC survival. But, there was a suggestion that an intronic SNP in $C A S R$, rs1354162, was associated with more favorable survival in colon cancer patients. The possible mechanisms explaining this association remain undetermined, particularly since rs1354162 is within an intron. Recent studies suggest that intronic SNPs have the potential to influence alternative splicing of RNA (Webb et al, 2003; ElSharawy et al, 2006). Interestingly, we found that the wildtype haplotype, G-G-G-G-G-A-C, in block 4 of CASR was associated with worse OS of colon cancer patients compared with the most common haplotype. Several SNPs defining this haplotype are nonsynonymous coding SNPs (that is, rs1801725 and rs1042636) or intron variants shown to be robustly associated with serum levels of calcium in recent GWAS studies (i.e., rs10222633 and rs10934578) (O'Seaghdha et al, 2013). We speculate that the region where these SNPs located may harbor a site of causative variants that in conjunction with each other impact on disease outcome; and these seven SNPs should be considered as candidate tag SNPs within the CASR gene for future association studies. Our results confirm with the theoretical expectation that haplotype-based approaches may have greater power than single-locus tests (Clark, 2004).

While it is unclear why CASR variation is related to survival only among colon cancer patients, and not rectal cancer patients, the difference in structure and cellular composition of the surface epithelium between colon (ciliated columnar epithelium) and lower rectum (squamous epithelium) may partially account. Alternatively, bile acids, formed in the liver and absorbed from the intestine has been shown to enhance intestinal proliferation and tumour yield (McMichael and Potter, 1985). Calcium could 
Table 3. Haplotypes on VDR and casr genes and associations with overall and disease-free survival among colorectal cancer patients $(n=531)$

Overall survival HR $(95 \% \mathrm{Cl})^{a}$

Disease-free survival HR $(95 \% \mathrm{Cl})^{a}$

\begin{tabular}{|c|c|c|c|c|c|c|c|}
\hline Haplotypes & Frequency $^{b}$ & All CRC & Colon cancer & Rectum cancer & All CRC & Colon cancer & Rectum cancer \\
\hline \multicolumn{8}{|c|}{ VDR, block $1^{\mathrm{c}}$} \\
\hline $\begin{array}{l}\text { GTG } \\
\text { GCA } \\
\text { ATG } \\
\text { Global } P^{d}\end{array}$ & $\begin{array}{l}0.5010 \\
0.4060 \\
0.0846\end{array}$ & $\begin{array}{l}1.00 \\
0.67(0.51-0.87) \\
0.96(0.61-1.50) \\
0.236\end{array}$ & $\begin{array}{l}1.00 \\
0.65(0.47-0.90) \\
0.64(0.46-1.16) \\
0.790\end{array}$ & $\begin{array}{l}1.00 \\
0.66(0.40-1.08) \\
2.53(1.20-5.34) \\
0.027\end{array}$ & $\begin{array}{l}1.00 \\
0.72(0.57-0.92) \\
0.87(0.58-1.31) \\
0.293\end{array}$ & $\begin{array}{l}1.00 \\
0.77(0.57-1.04) \\
0.81(0.48-1.36) \\
0.773\end{array}$ & $\begin{array}{l}1.00 \\
0.66(0.43-1.02) \\
1.31(0.65-2.64) \\
0.229\end{array}$ \\
\hline
\end{tabular}

\begin{tabular}{|c|c|c|c|c|c|c|c|}
\hline \multicolumn{8}{|c|}{ VDR, block $2^{\mathrm{e}}$} \\
\hline CTC & 0.4473 & 1.00 & 1.00 & 1.00 & 1.00 & 1.00 & 1.00 \\
\hline ACC & 0.1992 & $1.39(1.01-1.92)$ & $1.37(0.91-2.07)$ & $1.30(0.73-2.32)$ & $1.36(1.00-1.84)$ & $1.18(0.81-1.72)$ & $1.71(0.98-2.99)$ \\
\hline ATC & 0.1749 & $0.94(0.65-1.35)$ & $0.89(0.56-1.40)$ & $1.12(0.58-2.14)$ & $0.99(0.72-1.38)$ & $0.95(0.62-1.45)$ & $1.03(0.59-1.81)$ \\
\hline CTT & 0.1729 & $0.90(0.62-1.29)$ & $0.92(0.58-1.44)$ & $0.71(0.36-1.41)$ & $1.02(0.74-1.42)$ & $1.05(0.69-1.60)$ & $0.86(0.48-1.54)$ \\
\hline Global $P^{d}$ & & 0.325 & 0.559 & 0.470 & 0.923 & 0.967 & 0.880 \\
\hline
\end{tabular}

\begin{tabular}{|l|l|l|l|l|l|l|l|l}
\hline VDR, block $3^{f}$ \\
\hline GG & 0.7469 & 1.00 & 1.00 & 1.00 & 1.00 & 1.00 & $1.09(0.83-1.43)$ & $0.99(0.69-1.43)$ \\
AC & 0.2178 & $1.13(0.84-1.51)$ & $1.04(0.70-1.55)$ & $1.30(0.83-2.040)$ & $1.16(0.76-1.78)$ \\
AG & 0.0238 & $1.38(0.62-3.04)$ & $1.21(0.46-3.16)$ & $3.07(0.62-14.59)$ & $1.31(0.63-2.71)$ & $1.39(0.58-3.30)$ & $1.30(0.28-5.81)$ \\
GC & 0.0115 & $0.80(0.25-2.52)$ & $0.59(0.14-2.41)$ & $2.18(0.21-18.83)$ & $0.76(0.24-2.36)$ & $0.67(0.16-2.69)$ & $1.35(0.17-9.76)$ \\
Global Pd & & 0.638 & 0.897 & 0.228 & 0.550 \\
\hline
\end{tabular}

\begin{tabular}{|c|c|c|c|c|c|c|c|}
\hline \multicolumn{8}{|c|}{ VDR, block $4^{9}$} \\
\hline $\mathrm{CC}$ & 0.4176 & 1.00 & 1.00 & 1.00 & 1.00 & 1.00 & 1.00 \\
\hline TT & 0.4091 & $1.06(0.82-1.38)$ & $0.99(0.72-1.38)$ & $1.26(0.80-2.00)$ & $1.10(0.86-1.39)$ & $1.05(0.77-1.42)$ & $1.17(0.78-1.77)$ \\
\hline & 0.1698 & $1.09(0.77-1.53)$ & $0.95(0.60-1.51)$ & $1.36(0.80-2.33)$ & $1.09(0.80-1.50)$ & $0.98(0.65-1.48)$ & $1.19(0.72-1.97)$ \\
\hline Global $P^{d}$ & & 0.762 & 0.926 & 0.447 & 0.171 & 0.438 & 0.289 \\
\hline \multicolumn{8}{|c|}{ VDR, block $5^{\mathrm{h}}$} \\
\hline GG & 0.4044 & 1.00 & 1.00 & 1.00 & 1.00 & 1.00 & 1.00 \\
\hline TT & 0.3264 & $0.97(0.73-1.30)$ & $1.25(0.86-1.83)$ & $0.63(0.38-1.04)$ & $0.96(0.74-1.26)$ & $1.29(0.92-1.82)$ & $0.59(0.37-0.97)$ \\
\hline & 0.2667 & $1.03(0.77-1.38)$ & $1.19(0.81-1.75)$ & $0.87(0.55-1.38)$ & $1.08(0.82-1.41)$ & $1.26(0.88-1.80)$ & $0.82(0.53-1.27)$ \\
\hline Global $P^{d}$ & & 0.707 & 0.383 & 0.119 & 0.283 & 0.313 & 0.038 \\
\hline
\end{tabular}

\section{CASR, block $1^{i}$}

\begin{tabular}{|c|c|c|c|c|c|c|c|}
\hline $\begin{array}{l}\text { AG } \\
\text { AA } \\
\text { GA } \\
\text { Global } P^{d}\end{array}$ & $\begin{array}{l}0.6175 \\
0.1983 \\
0.1842\end{array}$ & $\begin{array}{l}1.00 \\
1.04(0.77-1.42) \\
0.90(0.65-1.24) \\
0.841\end{array}$ & $\begin{array}{l}1.00 \\
1.37(0.95-1.99) \\
1.06(0.72-1.57) \\
0.125\end{array}$ & $\begin{array}{l}1.00 \\
0.67(0.38-1.19) \\
0.65(0.37-1.14) \\
0.123\end{array}$ & $\begin{array}{l}1.00 \\
1.08(0.81-1.42) \\
0.87(0.64-1.17) \\
0.792\end{array}$ & $\begin{array}{l}1.00 \\
1.27(0.89-1.81) \\
1.03(0.70-1.50) \\
0.627\end{array}$ & $\begin{array}{l}1.00 \\
0.85(0.53-1.37) \\
0.66(0.39-1.11) \\
0.357\end{array}$ \\
\hline \multicolumn{8}{|c|}{ CASR, block $2^{j}$} \\
\hline $\begin{array}{l}\text { GGCC } \\
\text { AGCT } \\
\text { AGCC } \\
\text { GACC } \\
\text { AGAC } \\
\text { Global } P^{\text {d }}\end{array}$ & $\begin{array}{l}0.3272 \\
0.2284 \\
0.1860 \\
0.1617 \\
0.0911\end{array}$ & $\begin{array}{l}1.00 \\
0.74(0.54-1.02) \\
0.89(0.63-1.25) \\
0.65(0.45-0.96) \\
0.49(0.28-0.85) \\
0.070\end{array}$ & $\begin{array}{l}1.00 \\
0.70(0.46-1.06) \\
1.13(0.73-1.74) \\
0.74(0.47-1.19) \\
0.29(0.13-0.68) \\
0.047\end{array}$ & $\begin{array}{l}1.00 \\
0.91(0.55-1.50) \\
0.62(0.34-1.13) \\
0.50(0.24-1.05) \\
0.92(0.39-2.12) \\
0.477\end{array}$ & $\begin{array}{l}1.00 \\
0.76(0.57-1.02) \\
0.94(0.69-1.28) \\
0.67(0.47-0.96) \\
0.65(0.41-1.04) \\
0.300\end{array}$ & $\begin{array}{l}1.00 \\
0.72(0.49-1.05) \\
1.11(0.75-1.66) \\
0.80(0.51-1.23) \\
0.50(0.26-0.94) \\
0.113\end{array}$ & $\begin{array}{l}1.00 \\
0.91(0.59-1.41) \\
0.70(0.41-1.18) \\
0.49(0.25-0.95) \\
0.95(0.45-2.02) \\
0.490\end{array}$ \\
\hline \multicolumn{8}{|c|}{ CASR, block $3^{k}$} \\
\hline $\begin{array}{l}\text { CT } \\
\text { CC } \\
\text { TC } \\
\text { Global } P^{d}\end{array}$ & $\begin{array}{l}0.8618 \\
0.0846 \\
0.0536\end{array}$ & $\begin{array}{l}1.00 \\
1.02(0.66-1.57) \\
1.19(0.74-1.92) \\
0.910\end{array}$ & $\begin{array}{l}1.00 \\
1.19(0.70-2.05) \\
1.37(0.78-2.39) \\
0.741\end{array}$ & $\begin{array}{l}1.00 \\
0.86(0.40-1.84) \\
0.82(0.32-2.09) \\
0.819\end{array}$ & $\begin{array}{l}1.00 \\
1.19(0.81-1.76) \\
1.33(0.89-2.01) \\
0.677\end{array}$ & $\begin{array}{l}1.00 \\
1.13(0.68-1.89) \\
1.49(0.91-2.43) \\
0.617\end{array}$ & $\begin{array}{l}1.00 \\
1.37(0.77-2.46) \\
1.08(0.48-2.45) \\
0.908\end{array}$ \\
\hline \multicolumn{8}{|c|}{ CASR, block $4^{\prime}$} \\
\hline $\begin{array}{l}\text { AGGGGAC } \\
\text { AGGGGAT } \\
\text { GTGGTAC } \\
\text { GGAGGAC } \\
\text { GTGTGAC } \\
\text { GTGGGGC } \\
\text { GGGGGAC } \\
\text { GTGGGAC } \\
\text { Global } P^{d}\end{array}$ & $\begin{array}{l}0.3440 \\
0.1598 \\
0.1363 \\
0.1231 \\
0.0968 \\
0.0808 \\
0.0423 \\
0.0151\end{array}$ & $\begin{array}{l}1.00 \\
1.54(1.03-2.31) \\
1.10(0.73-1.65) \\
1.42(0.91-2.22) \\
1.11(0.66-1.88) \\
1.83(1.20-2.79) \\
2.30(1.33-3.98) \\
1.69(0.60-4.68) \\
0.015\end{array}$ & $\begin{array}{l}1.00 \\
1.55(0.93-2.59) \\
1.36(0.81-2.28) \\
1.62(0.96-2.76) \\
0.84(0.42-1.68) \\
2.34(1.38-3.97) \\
3.15(1.66-5.96) \\
3.05(0.85-10.63) \\
0.001\end{array}$ & $\begin{array}{l}1.00 \\
1.55(0.78-3.07) \\
0.68(0.32-1.42) \\
0.75(0.30-1.85) \\
1.66(0.70-3.93) \\
1.18(0.54-2.58) \\
0.75(0.21-2.69) \\
0.59(0.07-4.39) \\
0.423\end{array}$ & $\begin{array}{l}1.00 \\
1.46(1.01-2.10) \\
1.19(0.83-1.70) \\
1.40(0.94-2.09) \\
1.03(0.65-1.64) \\
1.56(1.07-2.28) \\
2.15(1.31-3.52) \\
1.16(0.39-3.31) \\
0.014\end{array}$ & $\begin{array}{l}1.00 \\
1.54(0.95-2.50) \\
1.39(0.88-2.20) \\
1.59(0.99-2.56) \\
0.82(0.44-1.54) \\
1.73(1.06-2.82) \\
3.25(1.80-5.85) \\
1.89(0.51-6.64) \\
0.001\end{array}$ & $\begin{array}{l}1.00 \\
1.48(0.82-2.66) \\
0.86(0.47-1.58) \\
0.88(0.39-1.99) \\
1.38(0.64-2.96) \\
1.21(0.64-2.28) \\
0.73(0.24-2.24) \\
0.45(0.06-3.21) \\
0.944\end{array}$ \\
\hline
\end{tabular}

Abbreviations: $\mathrm{CRC}=$ colorectal cancer; $\mathrm{HR}=$ hazard ratio. Those with significant $P$-values after Bonferroni correction for thirty-six haplotypes are shown in bold (i.e. the adjusted $P$-value at the 0.05 significance level is 0.0014 ).

${ }^{a}$ Cox proportional hazard model adjusted for age at diagnosis, sex, race, stage at diagnosis, reported screening procedure, marital status, and MSI status where applicable; subjects with missing information on tumour location $(n=14)$ were excluded from the stratified analysis.

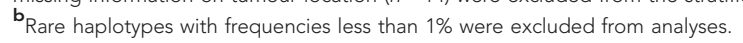

cVDR, block 1 includes rs 11574143 , rs731236, and rs1544410

$\mathbf{d}_{\text {Global } P}$ for association is from a Wald test with degrees of freedom equal to the number of haplotypes.

e VDR, block 2 includes rs2189480, rs2239186, and rs6580642.

$f_{V D R}$, block 3 includes rs 2238136 and rs 2238135 .

$\mathbf{9}_{\mathrm{VDR}}$, block 4 includes rs 2853564 and rs 4760648

$\mathbf{h}_{V D R}$, block 5 includes rs4328262 and rs 11168293 .

i CASR, block 1 includes rs 34028592 and rs6762782.

${ }^{j}$ CASR, block 2 includes rs1814740, rs35274320, rs1354162, and rs7637874.

${ }^{\mathbf{k}}$ CASR, block 3 includes rs 34345120 and rs 1463890 .

'CASR, block 4 includes rs10222633, rs10934578, rs3804592, rs17250717, rs1801725, rs1042636, and rs 1802757. 
bind to secondary bile acids to neutralise mucosal toxicity and reduce cell proliferation. The longer transit time in colon than rectum might simply allow more time for calcium to exert its action. Therefore, the CASR variants may be more influential in the progression of colon cancer where calcium may have a stronger protective effect.

A novel aspect of our study is the inclusion of gene-diet interaction. A previous study (Kim et al, 2013) on CASR polymorphisms (rs10934578, rs12485716, rs2270916, and rs4678174) and CRC risk has linked all four of these SNPs to an elevated risk of CRC only in the lower calcium category, which is consistent with our findings of a stronger effect of CASR variants in the low calcium group. Presumably the influence of subtle differences between genotypes was overwhelmed by the protective effect of high-dose calcium (Wong et al, 2003). Although the probability that these interactions are false-positive findings is high, this study still contributes to the overall evidence that calcium may act as a potential effect modifier in relation to the relationship between CASR genotypes and CRC survival. If the gene-nutrient interaction will be replicated in further studies, then cancer patients, especially those with detrimental genotypes, may benefit from the use of calcium supplements to improve their survival. Such supplementations should be based on well-designed and carefully conducted RCTs.

The strengths of the current study include its relatively large size, long follow-up period (up to 10 years), and detailed information on potential confounders and effect modifiers. Limitations to this study include a lack of the cause of death data for all deceased patients; however, we obtained the cause of death defined by ICD codes for 104 of 183 deceased patients; thereof the majority (90.4\%) was due to CRC. In addition, the lack of serum levels of 25-hydroxyvitamin D $(25(\mathrm{OH}) \mathrm{D})$ and calcium impeded us to test possible $25(\mathrm{OH}) \mathrm{D} / \mathrm{calcium}$-diet/gene interactions and to evaluate the extent to which the gene-CRC outcome association is mediated through serum levels of $25(\mathrm{OH}) \mathrm{D} /$ calcium. Besides, we cannot rule out effects of other genes with polymorphisms in the vitamin $\mathrm{D}$ and calcium metabolism pathway that may also influence the overall CRC initiation and progression. It is also notable that most SNPs examined in this work are tagging SNPs, which are selected merely as indicators for specific regions of interest; thus, there is a low probability that they are the causal SNPs (Egan et al, 2010). Therefore, first the replication of this work in other populations and then in detail examination of the other polymorphisms in the $V D R$ and $C A S R$ genes is necessary to identify truly causal variants.

\section{CONCLUSIONS}

Our results suggest that polymorphic variations of $V D R$ and $C A S R$ are associated with survival in patients with CRC. These findings indicate that certain variants of the VDR and CASR genes may be utilised as novel biomarkers for predicting prognosis in CRC patients.

\section{ACKNOWLEDGEMENTS}

We are very grateful to Dr Meera Jain and all those who contributed to data collection and data curation for the Newfoundland Familial Colorectal Cancer Study. This work was supported by the Canadian Institutes of Health Research Team Grant [CIHR-CPT79845] and Canadian Institutes of Health Research Team in Interdisciplinary Research on Colorectal Cancer Studentship [205835]. Yun Zhu was awarded by the Beatrice Hunter Cancer Research Institute (BHCRI) through a CRTP
Traineeship Award, the Newfoundland and Labrador Centre for Applied Health Research (NLCAHR) through a Doctoral Thesis Research Grant, and the Faculty of Medicine, Memorial University of Newfoundland through a Dean's Fellowship.

\section{CONFLICT OF INTEREST}

The authors declare no conflict of interest.

\section{AUTHOR CONTRIBUTIONS}

PPW, GZ, PSP, and JRM conceived and designed this study. YZ analysed the data and drafted the manuscript. PPW, PTC, JRW, IS, $\mathrm{YL}, \mathrm{XZ}, \mathrm{NY}$, and BB revised the paper. ED, PSP, GZ, SS, and JRM contributed to sample and data collection. All authors read and approved the final manuscript.

\section{REFERENCES}

Aggarwal A, Prinz-Wohlgenannt M, Tennakoon S, Hobaus J, Boudot C, Mentaverri R, Brown EM, Baumgartner-Parzer S, Kallay E (2015) The calcium-sensing receptor: a promising target for prevention of colorectal cancer. Biochim Biophys Acta 1853(9): 2158-2167.

Bacsi K, Hitre E, Kosa JP, Horvath H, Lazary A, Lakatos PL, Balla B, Budai B, Lakatos P, Speer G (2008) Effects of the lactase $13910 \mathrm{C} / \mathrm{T}$ and calciumsensor receptor A986S G/T gene polymorphisms on the incidence and recurrence of colorectal cancer in Hungarian population. BMC Cancer 8: 317.

Bai YH, Lu H, Hong D, Lin CC, Yu Z, Chen BC (2012) Vitamin D receptor gene polymorphisms and colorectal cancer risk: a systematic metaanalysis. World J Gastroenterol 18(14): 1672-1679.

Canaff L, Hendy GN (2002) Human calcium-sensing receptor gene. Vitamin D response elements in promoters P1 and P2 confer transcriptional responsiveness to 1,25-dihydroxyvitamin D. J Biol Chem 277(33): 30337-30350.

Carter KW, McCaskie PA, Palmer LJ (2008) SimHap GUI: an intuitive graphical user interface for genetic association analysis. $B M C$ Bioinformatics 9: 557.

Chattopadhyay N, Evliyaoglu C, Heese O, Carroll R, Sanders J, Black P, Brown EM (2000) Regulation of secretion of PTHrP by $\mathrm{Ca}(2+)$-sensing receptor in human astrocytes, astrocytomas, and meningiomas. Am J Physiol Cell Physiol 279(3): C691-C699.

Clark AG (2004) The role of haplotypes in candidate gene studies. Genet Epidemiol 27(4): 321-333.

Conneely KN, Boehnke M (2007) So many correlated tests, so little time! Rapid adjustment of P values for multiple correlated tests. Am J Hum Genet 81(6): 1158-1168.

de Bakker PI, Yelensky R, Pe'er I, Gabriel SB, Daly MJ, Altshuler D (2005) Efficiency and power in genetic association studies. Nat Genet 37(11): 1217-1223.

Dong LM, Ulrich CM, Hsu L, Duggan DJ, Benitez DS, White E, Slattery ML, Caan BJ, Potter JD, Peters U (2008) Genetic variation in calcium-sensing receptor and risk for colon cancer. Cancer Epidemiol Biomarkers Prev 17(10): 2755-2765.

Donohue MM, Demay MB (2002) Rickets in VDR null mice is secondary to decreased apoptosis of hypertrophic chondrocytes. Endocrinology 143(9): 3691-3694.

Egan JB, Thompson PA, Ashbeck EL, Conti DV, Duggan D, Hibler E, Jurutka PW, Leroy EC, Martinez ME, Mount D, Jacobs ET (2010) Genetic polymorphisms in vitamin $\mathrm{D}$ receptor VDR/RXRA influence the likelihood of colon adenoma recurrence. Cancer Res 70(4): 1496-1504.

ElSharawy A, Manaster C, Teuber M, Rosenstiel P, Kwiatkowski R, Huse K, Platzer M, Becker A, Nurnberg P, Schreiber S, Hampe J (2006) SNPSplicer: systematic analysis of SNP-dependent splicing in genotyped cDNAs. Hum Mutat 27(11): 1129-1134.

Fedirko V, Riboli E, Tjonneland A, Ferrari P, Olsen A, Bueno-de-Mesquita HB van Duijnhoven FJ, Norat T, Jansen EH, Dahm CC, Overvad K, Boutron-Ruault MC, Clavel-Chapelon F, Racine A, Lukanova A, 
Teucher B, Boeing H, Aleksandrova K, Trichopoulou A, Benetou V, Trichopoulos D, Grioni S, Vineis P, Panico S, Palli D, Tumino R, Siersema PD, Peeters PH, Skeie G, Brustad M, Chirlaque MD, Barricarte A, Ramon Quiros J, Sanchez MJ, Dorronsoro M, Bonet C, Palmqvist R, Hallmans G, Key TJ, Crowe F, Khaw KT, Wareham N, Romieu I, McKay J, Wark PA, Romaguera D, Jenab M (2012) Prediagnostic 25-hydroxyvitamin $\mathrm{D}, \mathrm{VDR}$ and CASR polymorphisms, and survival in patients with colorectal cancer in western European ppulations. Cancer Epidemiol Biomarkers Prev 21(4): 582-593.

Gabriel SB, Schaffner SF, Nguyen H, Moore JM, Roy J, Blumenstiel B, Higgins J, DeFelice M, Lochner A, Faggart M, Liu-Cordero SN, Rotimi C, Adeyemo A, Cooper R, Ward R, Lander ES, Daly MJ, Altshuler D (2002) The structure of haplotype blocks in the human genome. Science 296(5576): 2225-2229.

Gauderman WJ, Murcray C, Gilliland F, Conti DV (2007) Testing association between disease and multiple SNPs in a candidate gene. Genet Epidemiol 31(5): 383-395.

Giovannucci E, Liu Y, Rimm EB, Hollis BW, Fuchs CS, Stampfer MJ, Willett WC (2006) Prospective study of predictors of vitamin D status and cancer incidence and mortality in men. J Natl Cancer Inst 98(7): 451-459.

Green RC, Green JS, Buehler SK, Robb JD, Daftary D, Gallinger S, McLaughlin JR, Parfrey PS, Younghusband HB (2007) Very high incidence of familial colorectal cancer in Newfoundland: a comparison with Ontario and 13 other population-based studies. Fam Cancer 6(1): 53-62.

Harris DM, Go VL (2004) Vitamin D and colon carcinogenesis. J Nutr 134(12 Suppl): 3463S-3471S.

Heist RS, Zhou W, Wang Z, Liu G, Neuberg D, Su L, Asomaning K, Hollis BW, Lynch TJ, Wain JC, Giovannucci E, Christiani DC (2008) Circulating 25-hydroxyvitamin D, VDR polymorphisms, and survival in advanced non-small-cell lung cancer. J Clin Oncol 26(34): 5596-5602.

Hibler EA, Hu C, Jurutka PW, Martinez ME, Jacobs ET (2012) Polymorphic variation in the GC and CASR genes and associations with vitamin D metabolite concentration and metachronous colorectal neoplasia. Cancer Epidemiol Biomarkers Prev 21(2): 368-375.

Hubner RA, Muir KR, Liu JF, Logan RF, Grainge MJ, Houlston RS (2008) Dairy products, polymorphisms in the vitamin $\mathrm{D}$ receptor gene and colorectal adenoma recurrence. Int J Cancer 123(3): 586-593.

Ingles SA, Haile RW, Henderson BE, Kolonel LN, Nakaichi G, Shi CY, Yu MC, Ross RK, Coetzee GA (1997) Strength of linkage disequilibrium between two vitamin $\mathrm{D}$ receptor markers in five ethnic groups: implications for association studies. Cancer Epidemiol Biomarkers Prev 6(2): 93-98.

Ingles SA, Wang J, Coetzee GA, Lee ER, Frankl HD, Haile RW (2001) Vitamin D receptor polymorphisms and risk of colorectal adenomas (United States). Cancer Causes Control 12(7): 607-614.

Jacobs ET, Martinez ME, Campbell PT, Conti DV, Duggan D, Figueiredo JC, Haile RW, LeRoy EC, Poynter JN, Thompson PA, Baron JA (2010) Genetic variation in the retinoid X receptor and calcium-sensing receptor and risk of colorectal cancer in the Colon Cancer Family Registry. Carcinogenesis 31(8): 1412-1416.

Jenab M, McKay J, Bueno-de-Mesquita HB, van Duijnhoven FJ, Ferrari P, Slimani N, Jansen EH, Pischon T, Rinaldi S, Tjonneland A, Olsen A, Overvad K, Boutron-Ruault MC, Clavel-Chapelon F, Engel P, Kaaks R, Linseisen J, Boeing H, Fisher E, Trichopoulou A, Dilis V, Oustoglou E, Berrino F, Vineis P, Mattiello A, Masala G, Tumino R, Vrieling A, van Gils CH, Peeters PH, Brustad M, Lund E, Chirlaque MD, Barricarte A, Suarez LR, Molina E, Dorronsoro M, Sala N, Hallmans G, Palmqvist R, Roddam A, Key TJ, Khaw KT, Bingham S, Boffetta P, Autier P, Byrnes G, Norat T, Riboli E (2009) Vitamin D receptor and calcium sensing receptor polymorphisms and the risk of colorectal cancer in European populations. Cancer Epidemiol Biomarkers Prev 18(9): 2485-2491.

Jeong S, Kim JH, Kim MG, Han N, Kim IW, Kim T, Oh JM (2016) Genetic polymorphisms of CASR and cancer risk: evidence from meta-analysis and HuGE review. Onco Targets Ther 9: 655-669.

Kallay E, Pietschmann P, Toyokuni S, Bajna E, Hahn P, Mazzucco K, Bieglmayer C, Kato S, Cross HS (2001) Characterization of a vitamin D receptor knockout mouse as a model of colorectal hyperproliferation and DNA damage. Carcinogenesis 22(9): 1429-1435.

Kim KZ, Shin A, Kim J, Park JW, Park SC, Choi HS, Chang HJ, Kim DY, Oh JH (2013) Association between CASR polymorphisms, calcium intake, and colorectal cancer risk. PLoS One 8(3): e59628.
Laczmanska I, Laczmanski L, Bebenek M, Karpinski P, Czemarmazowicz H, Ramsey D, Milewicz A, Sasiadek MM (2014) Vitamin D receptor gene polymorphisms in relation to the risk of colorectal cancer in the Polish population. Tumour Biol 35(12): 12397-12401.

Leyssens C, Verlinden L, Verstuyf A (2013) Antineoplastic effects of $1,25(\mathrm{OH}) 2 \mathrm{D} 3$ and its analogs in breast, prostate and colorectal cancer. Endocr Relat Cancer 20(2): R31-R47.

Liu L, Wang PP, Roebothan B, Ryan A, Tucker CS, Colbourne J, Baker N, Cotterchio M, Yi Y, Sun G (2013) Assessing the validity of a selfadministered food-frequency questionnaire (FFQ) in the adult population of Newfoundland and Labrador, Canada. Nutr J 12: 49.

Mahmoudi T, Karimi K, Arkani M, Farahani H, Nobakht H, Dabiri R, Asadi A, Zali MR (2014) Parathyroid hormone gene rs6256 and calcium sensing receptor gene rs1801725 variants are not associated with susceptibility to colorectal cancer in Iran. Asian Pac J Cancer Prev 15(15): 6035-6039.

McMichael AJ, Potter JD (1985) Host factors in carcinogenesis: certain bileacid metabolic profiles that selectively increase the risk of proximal colon cancer. J Natl Cancer Inst 75(2): 185-191.

Miyamoto K, Kesterson RA, Yamamoto H, Taketani Y, Nishiwaki E, Tatsumi S, Inoue Y, Morita K, Takeda E, Pike JW (1997) Structural organization of the human vitamin $\mathrm{D}$ receptor chromosomal gene and its promoter. Mol Endocrinol 11(8): 1165-1179.

O'Seaghdha CM, Wu H, Yang Q, Kapur K, Guessous I, Zuber AM, Kottgen A, Stoudmann C, Teumer A, Kutalik Z, Mangino M, Dehghan A, Zhang W, Eiriksdottir G, Li G, Tanaka T, Portas L, Lopez LM, Hayward C, Lohman K, Matsuda K, Padmanabhan S, Firsov D, Sorice R, Ulivi S, Brockhaus AC, Kleber ME, Mahajan A, Ernst FD, Gudnason V, Launer LJ, Mace A, Boerwinckle E, Arking DE, Tanikawa C, Nakamura Y, Brown MJ, Gaspoz JM, Theler JM, Siscovick DS, Psaty BM, Bergmann S, Vollenweider P, Vitart V, Wright AF, Zemunik T, Boban M, Kolcic I, Navarro P, Brown EM, Estrada K, Ding J, Harris TB, Bandinelli S, Hernandez D, Singleton AB, Girotto G, Ruggiero D, d'Adamo AP, Robino A, Meitinger T, Meisinger C, Davies G, Starr JM, Chambers JC, Boehm BO, Winkelmann BR, Huang J, Murgia F, Wild SH, Campbell H, Morris AP, Franco OH, Hofman A, Uitterlinden AG, Rivadeneira F, Volker U, Hannemann A, Biffar R, Hoffmann W, Shin SY, Lescuyer P, Henry H, Schurmann C, Munroe PB, Gasparini P, Pirastu N, Ciullo M, Gieger C, Marz W, Lind L, Spector TD, Smith AV, Rudan I, Wilson JF, Polasek O, Deary IJ, Pirastu M, Ferrucci L, Liu Y, Kestenbaum B, Kooner JS, Witteman JC, Nauck M, Kao WH, Wallaschofski H, Bonny O, Fox CS, Bochud M (2013) Meta-analysis of genome-wide association studies identifies six new loci for serum calcium concentrations. PLoS Genet 9(9): e1003796.

Otani T, Iwasaki M, Sasazuki S, Inoue M, Tsugane S (2007) Plasma vitamin D and risk of colorectal cancer: the Japan Public Health Center-Based Prospective Study. Br J Cancer 97(3): 446-451.

Palmer HG, Gonzalez-Sancho JM, Espada J, Berciano MT, Puig I, Baulida J, Quintanilla M, Cano A, de Herreros AG, Lafarga M, Munoz A (2001) Vitamin $\mathrm{D}(3)$ promotes the differentiation of colon carcinoma cells by the induction of E-cadherin and the inhibition of beta-catenin signaling. J Cell Biol 154(2): 369-387.

Park K, Woo M, Nam J, Kim JC (2006) Start codon polymorphisms in the vitamin D receptor and colorectal cancer risk. Cancer Lett 237(2): 199-206.

Patterson RE, Neuhouser ML, Hedderson MM, Schwartz SM, Standish LJ, Bowen DJ (2003) Changes in diet, physical activity, and supplement use among adults diagnosed with cancer. J Am Diet Assoc 103(3): 323-328.

Perna L, Hoffmeister M, Schottker B, Arndt V, Haug U, Holleczek B, Burwinkel B, Ordonez-Mena JM, Brenner H (2013) Vitamin D receptor polymorphism and colorectal cancer-specific and all-cause mortality. Cancer Epidemiol 37(6): 905-907.

Peters U, McGlynn KA, Chatterjee N, Gunter E, Garcia-Closas M, Rothman N, Sinha R (2001) Vitamin D, calcium, and vitamin D receptor polymorphism in colorectal adenomas. Cancer Epidemiol Biomarkers Prev 10(12): $1267-1274$.

Sarkissyan M, Wu Y, Chen Z, Mishra DK, Sarkissyan S, Giannikopoulos I, Vadgama JV (2014) Vitamin D receptor FokI gene polymorphisms may be associated with colorectal cancer among African American and Hispanic participants. Cancer 120(9): 1387-1393.

Sheinin Y, Kallay E, Wrba F, Kriwanek S, Peterlik M, Cross HS (2000) Immunocytochemical localization of the extracellular calcium-sensing 
receptor in normal and malignant human large intestinal mucosa. J Histochem Cytochem 48(5): 595-602.

Slatter ML, Yakumo K, Hoffman M, Neuhausen S (2001) Variants of the VDR gene and risk of colon cancer (United States). Cancer Causes Control 12(4): 359-364.

Speer G, Cseh K, Mucsi K, Takacs I, Dworak O, Winkler G, Szody R, Tisler A Lakatos P (2002) Calcium-sensing receptor A986S polymorphism in human rectal cancer. Int J Colorectal Dis 17(1): 20-24.

Sun Z, Wang PP, Roebothan B, Cotterchio M, Green R, Buehler S, Zhao J, Squires J, Zhu Y, Dicks E, Campbell PT, McLaughlin JR, Parfrey PS (2011) Calcium and vitamin D and risk of colorectal cancer: results from a large population-based case-control study in Newfoundland and Labrador and Ontario. Can J Public Health 102(5): 382-389.

Tamez S, Norizoe C, Ochiai K, Takahashi D, Shimojima A, Tsutsumi Y, Yanaihara N, Tanaka T, Okamoto A, Urashima M (2009) Vitamin D receptor polymorphisms and prognosis of patients with epithelial ovarian cancer. Br J Cancer 101(12): 1957-1960.

Webb KE, Martin JF, Cotton J, Erusalimsky JD, Humphries SE (2003) The $4830 \mathrm{C}>\mathrm{A}$ polymorphism within intron 5 affects the pattern of alternative splicing occurring within exon 6 of the thrombopoietin gene. Exp Hematol 31(6): 488-494.

Wong HL, Seow A, Arakawa K, Lee HP, Yu MC, Ingles SA (2003) Vitamin D receptor start codon polymorphism and colorectal cancer risk: effect modification by dietary calcium and fat in Singapore Chinese.

Carcinogenesis 24(6): 1091-1095.
Woods MO, Younghusband HB, Parfrey PS, Gallinger S, McLaughlin J, Dicks E, Stuckless S, Pollett A, Bapat B, Mrkonjic M, de la Chapelle A, Clendenning M, Thibodeau SN, Simms M, Dohey A, Williams P, Robb D, Searle C, Green JS, Green RC (2010) The genetic basis of colorectal cancer in a population-based incident cohort with a high rate of familial disease. Gut 59(10): 1369-1377.

Zgaga L, Theodoratou E, Farrington SM, Din FV, Ooi LY, Glodzik D, Johnston S, Tenesa A, Campbell H, Dunlop MG (2014) Plasma vitamin D concentration influences survival outcome after a diagnosis of colorectal cancer. J Clin Oncol 32(23): 2430-2439.

Zhou W, Heist RS, Liu G, Neuberg DS, Asomaning K, Su L, Wain JC, Lynch TJ, Giovannucci E, Christiani DC (2006) Polymorphisms of vitamin D receptor and survival in early-stage non-small cell lung cancer patients. Cancer Epidemiol Biomarkers Prev 15(11): 2239-2245.

Zhu Y, Yang SR, Wang PP, Savas S, Wish T, Zhao J, Green R, Woods M, Sun Z, Roebothan B, Squires J, Buehler S, Dicks E, McLaughlin JR, Parfrey PS, Campbell PT (2014) Influence of pre-diagnostic cigarette smoking on colorectal cancer survival: overall and by tumour molecular phenotype. Br J Cancer 110(5): 1359-1366.

This work is published under the standard license to publish agreement. After 12 months the work will become freely available and the license terms will switch to a Creative Commons AttributionNonCommercial-Share Alike 4.0 Unported License.

Supplementary Information accompanies this paper on British Journal of Cancer website (http://www.nature.com/bjc) 